\title{
PENGEMBANGAN SAPI POTONG DI KABUPATEN RAJA AMPAT BERDASARKAN KARAKTERISTIK WILAYAH DAN TERNAK
}

\section{THE BEEF CATTLE DEVELOPMENT BASED ON THE REGION AND BREED CHARACTERISTICS IN THE DISTRICT OF RAJA AMPAT}

\author{
Rajab, Mochammad S. Soltief
}

Jurusan Peternakan Fakultas Pertanian, Universitas Pattimura

Jln. Ir. M. Putuhena, Kampus Poka - Ambon, Kode Pos. 97233

Penulis korespondensi email: rajab.amir@gmail.com

\begin{tabular}{|l|l}
\hline Diterima : 2 Desember 2017 & Disetujui : 17 Desember 2017
\end{tabular}

\section{Intisari}

Sapi Bali sebagai sapi potong yang banyak diusahakan di Kabupaten raja Ampat umumnya dipelihara secara tradisional ekstensif. Kondisi pemeliharaan sapi potong ini didukung dengan wilayah yang masih luas dan sumber hijauan makanan ternak serta konsentrat yang belum dimanfaatkan secara optimal. Penelitian ini bertujuan untuk mengidentifikasi dan menganalisa prospek pengembangan usaha sapi potong di Kabupaten Raja Ampat ditinjau dari aspek potensi wilayah dan potensi ternaknya. Penelitian ini menggunakan metode survey dengan cara wawancara terhadap responden berjumlah 218 orang dan pengamatan langsung di lapangan berlokasi di Kampung Sakabu, Kalobo dan Waijan yang merupakan sentra pengembangan sapi potong. Hasil penelitian menunjukkan kemampuan pengembangan sapi potong di Kabupaten Raja Ampat dapat mencapai 17.792,55 ST, namum bila ditinjau dari aspek produktivitasnya sapi potong yang dipelihara memiliki bobot badan yang masih rendah. Pengurangan jumlah penjualan ternak unggul dalam populasi dan penerapan sistem integrasi tanaman ternak dapat menjadi solusi bagi pengembangan usaha sapi potong ke depan.

Kata kunci: pengembangan sapi potong, potensi wilayah, potensi ternak

\begin{abstract}
As beef cattle, Bali cattle which rearing by the breeder in Raja Ampat regency most in the traditional extensive system. There are many factors to support beef cattle development in this region such as widely land condition with grass forage and feed concentrate as feed for cattle. The objectives of this study were to identification and analysis beef cattle development in Raja Ampat regency base on region and breed potential. Using survey method by interview to 218 of respondent and field observation were done in Sakabu, Kalobo and Waijan Village which tended as the center of beef cattle breeding. The result showed that beef cattle development reach out for 17,792.55 UT, but in productivity factor, Bali cattle in Raja Ampat was small in body weight. To increase beef cattle production and population can be done by reduced beef productive selling and by using an integrated farming system. Based on the potential of territory, the capability of beef cattle development in Raja Ampat regency can reach 17,792,55 ST, so from that number, the research location is potential to be directed to be the beef cattle development area. However, when viewed from the aspect of productivity, beef cattle are maintained have a lower body weight than other regions, indicating a decrease in performance and genetic quality. Reduction in the number of livestock sales in the population and the application of crop-livestock integration systems can be the solution.
\end{abstract}

Keywords : beef cattle development, land potential, breed characteristics 


\section{PENDAHULUAN}

Upaya membangun dan mengembangkan kabupaten yang memiliki potensi sumber daya alam yang belum termanfaatkan secara optimal memerlukan suatu perencanaan pengelolaan yang tepat dan bijak demi kemakmuran masyarakat umumnya dan khususnya di Kabupaten Raja Ampat. Salah satu sektor yang berpotensi dan sangat cocok untuk dikembangkan di Kabupaten Raja Ampat adalah pertanian termasuk subsektor peternakan. Komoditas peternakan yang dapat dikembangkan di daerah ini adalah sapi potong. Kondisi wilayah yang luas memungkinkan

pembentukan/pengembangan suatu kawasan budidaya sapi potong guna peningkatan ketahanan pangan untuk mewakili kebutuhan masyarakat akan protein hewani, peningkatan pendapatan petani peternak dan pendapatan asli daerah (PAD) (Bamualim, 2007).

Sapi Bali sebagai sapi potong yang banyak diusahakan di Kabupaten Raja Ampat umumnya dipelihara secara tradisional ekstensif oleh penduduk transmigran yang berasal dari Jawa dan bersifat sampingan terhadap kegiatan usaha tani sawah sebagai usaha utama. Kondisi pemeliharaan sapi potong ini didukung dengan wilayah daratan yang masih luas jika dilihat berdasarkan tingkat kepadatan penduduk di kabupaten Raja Ampat yaitu 7 jiwa/ $/ \mathrm{km}^{2}$ (BPS Kabupaten Raja Ampat, 2014) dan sumber hijauan makanan ternak serta konsentrat yang belum dimanfaatkan secara optimal.

Sistem budidaya sapi potong pada saat ini masih menghadapi berbagai kendala antara lain; (a) kesulitan untuk memperoleh bibit, (b) masih tingginya angka pemotongan ternak betina produktif, (c) rendahnya angka kelahiran dan tingginya angka kematian ternak, (d) rendahnya tingkat keberhasilan teknologi Inseminasi Buatan (IB), (e) belum diterapkan teknologi pakan aplikatif, (f) tingginya harga obat hewan, (g) kesulitan untuk akses ke sumber modal, (h) rendahnya nilai tambah yang diperoleh peternak dan (i) masih kurangnya upaya pemanfaatan limbah pertanian dan ternak sebagai sumber pakan, sumber energi dan pupuk organik (Bamualim dkk., 2008).

Kebutuhan asal ternak berupa daging, susu dan telur saat ini masih disuplai dari Kabupaten Sorong, karena terbatasnya ketersediaan dari dalam. Disparitas antara suplai dan permintaan/ kebutuhan menunjukkan bahwa upaya pengembangan sapi potong perlu dilakukan. Hal ini didukung oleh adanya 
peluang pemasaran daging sapi yang relatif besar dengan adanya perusahaanperusahaan pertambangan di sekitar wilayah Kabupaten Raja Ampat yang siap menerima pasokan daging sapi. Kebutuhan daging sapi untuk PT Freeport Indonesia sebesar 1500 ton per bulan dan $70 \%$ berasal dari Australia, untuk Petrocina Oil sebesar 350 ton per bulan yang semuanya dipasok dari luar Provinsi Papua (Distannakbun Raja Ampat, 2009).

Potensi wilayah yang mendukung serta ketersediaan bahan baku pakan dan sumber daya manusia memungkinkan pengembangan sapi potong berbasis sumber daya lokal di wilayah tersebut. Untuk mengetahui kapasitas wilayah diperlukan adanya kajian mengenai

kawasan sapi potong berbasis kerakyatan yang tepat di Kabupaten Raja Ampat sehingga dapat menjadi acuan dalam arah pengembangan sapi potong selanjutnya guna peningkatan kesejahteraan masyarakat Raja Ampat dan pendapatan asli daerah.

Penelitian ini bertujuan untuk mengidentifikasi dan menganalisa prospek pengembangan usaha sapi potong di Kabupaten Raja Ampat ditinjau dari aspek potensi wilayah dan potensi ternaknya. Diharapkan dari penelitian ini dapat memberikan data dasar sebagai informasi ilmiah bagi institusi terkait dalam merumuskan kebijakan dan strategi pengembangan sapi potong di Kabupaten Raja Ampat.

\section{METODE PENELITIAN}

\section{Lokasi dan Waktu Penelitian}

Penelitian ini dilaksanakan selama 3 bulan dengan lokasi penelitian adalah Kampung Sakabu, Kalobo dan Waijan, Distrik Salawati Utara Kabupaten Raja Ampat Provinsi Papua Barat. Beberapa pertimbangan pemilihan lokasi ini adalah (1) lebih dari $95 \%$ populasi sapi potong (sapi Bali) berada pada lokasi ini, dan (2) berdasarkan RTRW Kabupaten Raja Ampat, lokasi ini diproyeksikan sebagai kawasan agropolitan dengan sentra pengembangan sapi potong di Kabupaten Raja Ampat (Bappeda Raja Ampat, 2008).

\section{Metode Pengumpulan Data dan Responden}

Penelitian ini menggunakan metode survey dengan cara wawancara menggunakan daftar pertanyaan (questioner) terhadap responden berjumlah 218 orang yakni seluruh peternak yang memiliki sapi potong dan pengamatan langsung di lapangan. Pengamatan langsung dilakukan dengan cara pengukuran sampel sapi dan pengamatan visual untuk memperoleh informasi 
tentang kondisi dan pola pemeliharaan di lokasi penelitian dan padang penggembalaan yang ada.

Data yang dikumpulkan mencakup (1) data sekunder yang diperoleh dari Bappeda Kabupaten Raja Ampat, Dinas Pertaniaan Peternakan dan Perkebunan Kabupaten Raja Ampat ; dan (2) data primer, yang berasal dari data hasil wawancara dengan responden dan pengamatan di lapangan.

Peubah yang akan diamati dalam penelitian ini meliputi: (1) Karakteristik wilayah (meliputi kondisi iklim, tanah, topografi, potensi wilayah dan daya dukung lahan untuk mengetahui kapasitas tampung ternak) ; dan (2) Karakteristik produksi ternak meliputi populasi, tingkat kelahiran, tingkat kematian, jumlah pengeluaran dan pemasukan ternak, jumlah pemotongan, dan estimasi bobot badan melalui pengukuran beberapa ukuran tubuh.

\section{Analisis Data}

Data yang diperoleh dianalisis secara deskriptif, dan disajikan dalam bentuk Tabel. Kapasitas tampung ternak ruminansia dalam suatu wilayah menunjukkan populasi maksimum ternak sapi potong yang dapat ada di wilayah tersebut berdasarkan ketersediaan pakan hijauan. Untuk mengetahui kapasitas pengembangan ternak sapi potong, data yang diperoleh dianalisis lebih lanjut menggunakan penghitungan Kapasitas Peningkatan Populasi Ternak Ruminansia (KPPTR) mengacu pada Direktorat Jendral Peternakan (1994), sebagai berikut:

1) $\mathrm{PMSL}=\mathrm{a} \mathrm{LG}+\mathrm{b} \mathrm{PR}+\mathrm{c} \mathrm{LH}$

Keterangan :

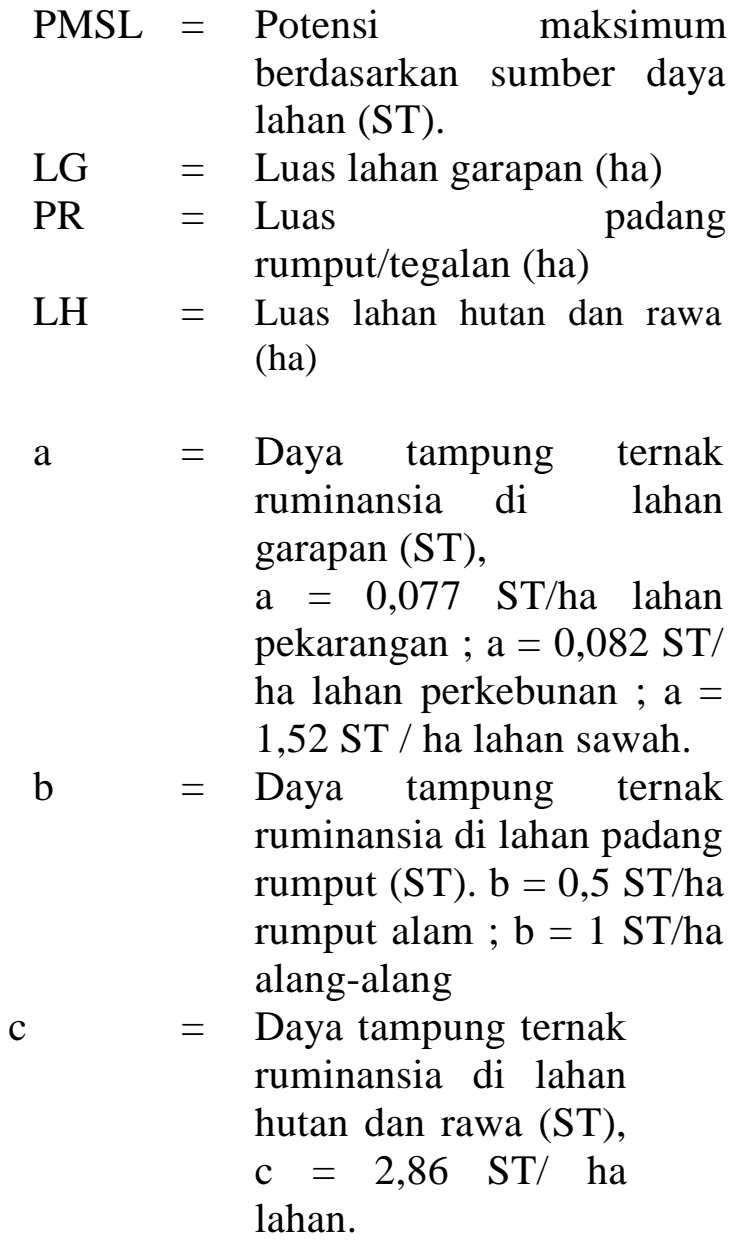

2) $\quad \operatorname{KPPTR}(\mathrm{SL})=\mathrm{PMSL}-\mathrm{POPRI} \ldots$ (2)

Keterangan :

$\begin{array}{rlr}\text { KPPTR }= & \begin{array}{l}\text { Kapasitas peningkatan } \\ \text { populasi ternak ruminansia } \\ \text { berdasarkan sumber daya } \\ \text { lahan }(\mathrm{ST})\end{array} \\ \text { POPRIL }=\begin{array}{ll}\text { Populasi riil ternak } \\ \text { ruminansia }\end{array} & \end{array}$

3) PMKK = $a^{*} \mathrm{KK}$ 
Keterangan ;

$$
\begin{aligned}
\text { PMKK = } & \text { Potensi maksimum usaha } \\
& \text { ternak }(\mathrm{ST}) \text { berdasarkan } \\
& \text { kepala keluarga } \\
\mathrm{KK}= & \text { Kepala Keluarga } \\
\mathrm{a}= & \text { Kemampuan rumah tangga } \\
& \text { untuk usaha ternak } \\
& \text { rumnansia tanpa tenaga } \\
& \text { kerja dari luar rumah } \\
& \text { tangga } \mathrm{a}=3 \mathrm{ST} / \mathrm{KK} .
\end{aligned}
$$

Produktivitas sapi potong dievaluasi dan diukur berdasarkan estimasi bobot badan sapi Bali yang diamati untuk menggambarkan kondisi produktifitas ternak yang dipelihara. Data bobot badan diperoleh melalui pendugaan menggunakan karakteristik morfometrik ternak yang didapat dengan cara pengukuran. Pendugaan bobot badan menggunakan data yang diperoleh berdasarkan hasil penelitian Rajab (2009). Untuk membandingkan performa produksi (bobot badan) sapi potong digunakan Uji-t (Musa dan Nasution, 2007). Analisis data menggunakan software MINITAB versi 14.0.

\section{HASIL DAN PEMBAHASAN}

\section{Karakteristik dan Potensi Wilayah}

\section{Kondisi Iklim, Tanah dan Topografi}

Wilayah Distrik Salawati Utara yang telah ditetapkan sebagai kawasan pengembangan peternakan khususnya sapi potong mencakup tiga kampung yaitu kampung Sakabu, Kalobo dan Waijan yang menjadi lokasi target penelitian ini. Ketiga kampung ini terletak di sebelah selatan Pulau Salawati dan saling berbatasan satu dengan lainnya, dimana kampung Kalobo dan Waijan berada pada daerah lembah dataran rendah dengan ketinggian tempat kurang dari $100 \mathrm{~m} \mathrm{dpl}$ dan sebagian besar dihuni oleh penduduk transmigran asal Jawa, sedangkan kampung Sakabu berada di pesisir pantai dan umumnya dihuni oleh masyarakat pribumi (asli Papua). Secara umum, kondisi iklim, jenis tanah dan topografi lokasi penelitian dapat dilihat pada Tabel 1.

Secara geografis lokasi penelitian memiliki iklim tropis yang lembab dan panas, curah hujan relatif tinggi $( \pm 211,42$ $\mathrm{mm} /$ bulan) dan merata sepanjang tahun. Kondisi ini sangat mendukung pertumbuhan hijauan dan leguminosa sehingga dapat menjamin ketersediaan dan kontinuitasnya sebagai sumber pakan ternak sapi potong sepanjang tahun. Ratarata temperatur udara $27,4^{\circ} \mathrm{C}$ dengan kisaran temperatur terendah sebesar 23,9 ${ }^{\circ} \mathrm{C}$, tertinggi $33,1^{\circ} \mathrm{C}$. Kelembaban berkisar 
antara $79 \%-87 \%$ dengan rata-rata radiasi penyinaran matahari sebesar $60 \%$ tiap tahun. Menurut Hidayati dkk. (2001) saat terbaik bagi pertumbuhan dan produksi padang rumput dan leguminosa berada pada kondisi iklim dengan temperatur 27 ${ }^{\circ} \mathrm{C}$, kelembaban antara $70-80 \%$ dan radiasi matahari $60-80 \%$. Kondisi ini juga sesuai dengan kondisi optimal untuk sapi potong daerah tropis guna mendukung aktifitas reproduksinya (Talib dkk., 1999). Ditinjau dari aspek jenis bibit ternak sapi potong lokal yang diusahakan, maka kondisi iklim ini sangat memungkinkan bagi pengembangan sapi lokal Indonesia (sapi Bali) karena pada umumnya mempunyai kemampuan beradaptasi baik pada lingkungan iklim tropis dengan kersediaan pakan berkualitas rendah (Handiwirawan \& Subandriyo, 2004).

Tabel 1. Kondisi iklim, jenis tanah dan topografi lokasi penelitian

\begin{tabular}{|c|c|c|c|c|}
\hline \multirow{2}{*}{ No. } & \multirow{2}{*}{ Uraian (Peubah diamati) } & \multicolumn{3}{|c|}{ Lokasi Penelitian } \\
\hline & & Sakabu & Kalobo & Waijan \\
\hline \multirow[t]{6}{*}{1} & Iklim & & & \\
\hline & .. Curah hujan (mm/thn) & & 2537 & \\
\hline & 1. Temperatur rata-rata $\left({ }^{\circ} \mathrm{C}\right)$ & & 27,7 & \\
\hline & $\therefore$ Kelembaban $(\%)$ & & 84 & \\
\hline & I. Tekanan udara (mbs) & & $1.010,7$ & \\
\hline & $\therefore$ Penyinaran matahari $(\%)$ & & 60 & \\
\hline \multirow[t]{11}{*}{2} & Jenis tanah dan topografi & & & \\
\hline & .. Ketinggian tempat (dpl) & $0-25$ & 25 & $25-50$ \\
\hline & 1. Kemiringan lahan (\%) & $0-40$ & $<8$ & $0-40$ \\
\hline & Jenis tanah & Podsolik+ & Podsolik & Podsolik \\
\hline & I. Tekstur tanah & Aluvial & Sedang & Sedang \\
\hline & $\therefore$ Tingkat kesuburan & Sedang & Sedang & Sedang \\
\hline & Kedalaman efektif $(\mathrm{cm})$ & Subur, & $25-50$ & $50-100$ \\
\hline & .. Kondisi air tanah & sedang & Agak & Agak rendah, \\
\hline & & $0-100$ & rendah, & Sedang \\
\hline & & Agak & Sedang & \\
\hline & & rendah & & \\
\hline
\end{tabular}

Sumber: Bappeda Kabupaten Raja Ampat (2009)

Topografi wilayah penelitian yang didominasi oleh wilayah dataran disertai areal perbukitan, dengan ketinggian antara 0 sampai $50 \mathrm{~m}$ dari permukaan laut (dpl) serta kemiringan lahan antara 0-40\%. Diperkirakan kondisi lahan yang datar sebesar $45 \%$ sedangkan sisanya sebesar $65 \%$ lahan merupakan daerah perbukitan dengan ketinggian tidak lebih dari $25 \mathrm{~m}$ dpl. Jenis tanah podsolik berwarna merah kuning dan aluvial coklat dengan tekstur tanah sedang, menunjukkan tingkat kesuburan tanah sedang sampai subur. Air tersedia secara cukup untuk memenuhi kebutuhan konsumsi untuk minum ternak, memandikan/ membersihkan ternak, pertumbuhan hijauan pakan ternak, dan kebutuhan lainnya. Menurut Harjowigeno dan 
Widiatmaka (2006), kondisi media perakaran yang sesuai untuk padang penggembalaan sebagai sumber pakan ternak yaitu tekstur tanah sedang (lempung liat berpasir), kedalaman efektif $>30 \mathrm{~cm}$, dan drainase tanah agak terhambat sampai sedang. Secara umum kondisi lokasi penelitian yang didominasi oleh wilayah yang datar akan sangat cocok dan potencial bagi pengembangan sapi potong, apalagi dengan didukung oleh $\pm 50-60 \%$ daerah dataran yang berupa padang rumput sebagai sumber pakan sapi potong.

\section{Potensi Wilayah dan Daya Dukung Lahan}

Lahan merupakan lingkungan fisik yang meliputi tanah, iklim, relief, hidrologi dan vegetasi, dimana faktorfaktor tersebut mempengaruhi potensi penggunaanya, termasuk didalamnya adalah akibat-akibat kegiatan manusia (Rayes, 2007). Dalam usaha sapi potong, lahan merupakan basis untuk usaha dan sebagai tempat terselenggaranya kegiatan produksi. Kebutuhan lahan bagi pengembangan ternak ruminansia seperti sapi potong penting terutama sebagai sumber pakan seperti rumput (graminae), leguminosa dan hijauan dari tumbuhan lain seperti daun nangka, daun waru dan lain sebagainya. Hasil survey terhadap potensi wilayah dan daya dukung lahan pada lokasi penelitian secara umum seperti tertera pada Tabel 2.

Hasil penelitian menunjukkan bahwa sumberdaya lahan yang dapat dimanfaatkan untuk ternak pengembangan sapi potong di Kabupaten Raja Ampat antara lain: lahan sawah, padang pengembalaan/padang rumput, lahan perkebunan, hutan dan lahan pekarangan. Luas lahan tersebut dengan tingkat kepadatan penduduk yang relatif masih rendah $\left(\leq 10 \quad \mathrm{jiwa} / \mathrm{km}^{2}\right)$ memungkinkan pengembangan pola integrasi ternak dengan tanaman perkebunan dan perikanan di kampung Sakabu, atau pola integrasi ternak dengan tanaman pertanian atau tanaman padi di kampung Kalobo dan Waijan, yang mana pola integrasi ini merupakan suatu proses saling menunjang dan saling menguntungkan. Pemanfaatan pola integrasi diharapkan dapat meningkatkan ketersediaan pakan sepanjang tahun, sehingga dapat meningkatkan produktivitas ternak (Riady, 2004). Optimalisasi pemanfaatan lahan tidak lagi secara monokultur tetapi dilakukan dengan sistem yang terintegrasi dengan komoditas lain, seperti perkebunan atau tanaman padi sebagai sumber pakan bagi ternak ruminansia. Berdasarkan luas lahan sawah di kampung Kalobo dan 
Waijan dengan rata - rata produksi gabah kering giling 2.5 ton/ha/panen (Distannakbun Raja Ampat, 2009) dapat menghasilkan limbah berupa dedak padi sebanyak 472 ton, jumlah ini dapat digunakan sebagai pakan konsentrat untuk 2.098 satuan ternak (ST). Disamping itu produksi jerami padi dapat mencapai 7.221 ton/panen, menurut Suratman dkk. (1998) setiap hektar sawah mampu menghasilkan jerami padi 5-8 ton/ha/panen. Jerami padi ini dapat digunakan sebagai pakan alternative untuk $\pm 2.865,7$ ST sepanjang tahun.

Tabel 2. Potensi wilayah dan daya dukung lahan lokasi penelitian

\begin{tabular}{|c|c|c|c|c|}
\hline \multirow{2}{*}{ No } & \multirow{2}{*}{ Uraian (Peubah Diamati) } & \multicolumn{3}{|c|}{ Lokasi Penelitian } \\
\hline & & Sakabu & Kalobo & Waijan \\
\hline \multirow{2}{*}{$\begin{array}{l}1 \\
2\end{array}$} & Luas Lahan (Ha) & 2.887 & 5.579 & 4.283 \\
\hline & Kepadatan Penduduk (jiwa/km2) & 10,8 & 9,5 & 8,9 \\
\hline \multirow{2}{*}{$\begin{array}{l}3 \\
4\end{array}$} & Luas Lahan Pangan (Ha) & 83 & 1.424 & 1.021 \\
\hline & $\begin{array}{l}\text { Nisbah Lahan Pangan Terhadap } \\
\text { Penduduk (jiwa/ha) }\end{array}$ & 4,75 & 0,47 & 0,48 \\
\hline \multirow[t]{6}{*}{5} & Tata Guna Lahan : & & & \\
\hline & a. Luas hutan (ha) & 2057 & 1399 & 1726 \\
\hline & b. Luas padang rumput (ha) & 686 & 2599 & 1413 \\
\hline & c. Luas sawah (ha) & 0 & 655 & 456 \\
\hline & d. Luas perkebunan (ha) & 119 & 769 & 565 \\
\hline & e. Luas pekarangan (ha) & 25 & 157 & 123 \\
\hline 6 & $\operatorname{PMSL}(\mathrm{ST})^{\mathbf{a}}$ & 6237.703 & 6371.387 & 6391.781 \\
\hline 7 & Populasi saat ini (ST) & 35.2 & 657,95 & 515,15 \\
\hline 8 & $\operatorname{KPPTR}(\mathrm{ST})^{\mathbf{b}}$ & 6202,50 & 5713,42 & 5876,63 \\
\hline 9 & $\operatorname{PMKK}(\mathrm{ST})^{\mathbf{c}}$ & 291 & 429 & 339 \\
\hline \multirow[t]{2}{*}{10} & Pola dasar Pembangunan & Lahan & Lahan & Lahan \\
\hline & & $\begin{array}{l}\text { Pertanian, } \\
\text { pemukiman }\end{array}$ & $\begin{array}{l}\text { Pertanian, } \\
\text { pemukiman }\end{array}$ & $\begin{array}{l}\text { Pertanian, } \\
\text { pemukiman }\end{array}$ \\
\hline 11 & Pola Pertanian & $\begin{array}{l}\text { Perikanan } \\
\text { tradisional }\end{array}$ & $\begin{array}{l}\text { persawahan, } \\
\text { palawija }\end{array}$ & $\begin{array}{c}\text { persawahan, } \\
\text { palawija }\end{array}$ \\
\hline 12 & Sarana Irigasi & Non-irigasi & Irigasi teknis & Irigasi teknis \\
\hline
\end{tabular}

Sumber : Bappeda Raja Ampat (2007)

Keterangan: a. PMSL = Potensi Maksimum berdasarkan Sumber Daya Lahan

b. KPPTR = Kapasitas Peningkatan Populasi Ternak Ruminansia

c. $\mathrm{PMKK}=$ Potensi Maksimum Usaha Ternak berdasarkan Kepala Keluarga

Sistem penggunaan lahan di lokasi penelitian terbagi atas lahan usaha dan lahan pekarangan dengan status kepemilikan lahan berupa hak milik bagi masyarakat transmigran (kampung Kalobo dan Waijan) dan hak ulayat bagi penduduk asli (kampung Sakabu). Umumnya lahan usaha hanya sebagian dipergunakan untuk tanaman padi sawah dan selebihnya tidak digarap. Kondisi ini umumnya 
dimanfaatkan sebagai areal penggembalaan ternak karena selalu tersedianya HMT sebagai sumber pakan sapi potong. Kebutuhan lahan untuk usaha ternak ruminansia dapat dibedakan menjadi dua: 1) usaha peternakan yang berbasis lahan (land base agriculture); dan 2) usaha peternakan yang tidak berbasis lahan (non land base agriculture). Menurut Suratman et al. (1998) Khusus untuk peternakan berbasis lahan ternak dengan komponen pakannya sebagian besar terdiri atas tanaman hijauan (rumput dan leguminosa), lahan merupakan faktor lingkungan hidup dan pendukung pakan. Agar ternak dapat berproduksi dengan baik, perlu diperhatikan persyaratan penggunaan dari sifat-sifat pembatas lahan yang meliputi sekelompok kualitas lahan yang diperlukan dan yang mempunyai pengaruh merugikan untuk produksi ternak (Hardjowigeno \& Widiatmaka, 2006).

Hasil analisis daya dukung lahan/wilayah berdasarkan atas potensi maksimum sumber daya lahan dan kemampuan menghasilkan hijauan pakan ternak secara alami, menunjukkan bahwa populasi sapi potong tahun 2008 dan daya tampung wilayah untuk ternak sapi potong masih cukup memadai sebagaimana disajikan pada Tabel 2. Berdasarkan hasil analisis, jumlah ternak sapi potong yang masih dapat dikembangkan di masing- masing kampung Sakabu, Kalobo dan Waijan memenuhi daya tampung tersebut sebesar 6202,50 ST, 5713,42 ST, dan 5876,63 ST. Apabila pembangunan peternakan diarahkan pada pengembangan sapi potong dengan pola integrasi, atau secara intensifikasi, daya tampung tersebut dapat ditingkatkan. Prioritas lokasi pengembangan sapi potong di Kabupaten Raja Ampat yang perlu dioptimalkan pengelolaannya adalah

lokasi perkebunan tanaman buah-buahan (durian) di kampung Sakabu, (2) lokasi pertanian tanaman padi yang tersebar di Kampung Kalobo dan Waijan, (3) perkampungan ternak sapi di ketiga kampung dengan lahan total mencapai 12.749 ha dengan kemampuan peningkatan populasi sapi potong sebesar 17.792,55 ST, sehingga dari jumlah tersebut terlihat bahwa lokasi penelitian cukup potensial untuk dikembangkan menjadi kawasan pengembangan sapi potong.

\section{Karakteristik Produksi Ternak Sapi Potong}

Data produktivitas sapi potong meliputi bobot badan dapat dilihat pada Tabel 3. Bobot badan sapi Bali jantan dan betina yang berumur $<1$ tahun didapati hampir sama pada ketiga lokasi penelitian. Pertumbuhan anak sapi pada masa prasapih umumnya dipengaruhi oleh 
kemampuan pedet memperoleh nutrisi yang berasal dari air susu induknya. Penampilan produksi berupa bobot badan sapi Bali betina umur $>1$ sampai $\leq 2$ tahun yang tidak menunjukkan perberbedaan, ini berkaitan dengan system pemeliharaan yang relatif sama di ketiga lokasi, semua ternak sapi jantan di Kampung Kalobo memiliki ukuran tubuh yang lebih besar.

Tabel 3. Rataan bobot badan sapi Bali di kampung Sakabu,Kalobo dan Waijan Kabupaten Raja Ampat berdasarkan jenis kelamin dan umur.

\begin{tabular}{|c|c|c|c|c|c|c|c|}
\hline \multirow[b]{3}{*}{ No } & \multirow{3}{*}{$\begin{array}{l}\text { Umur } \\
\text { (Tahun) }\end{array}$} & \multicolumn{6}{|c|}{ lokasi Penelitian } \\
\hline & & \multicolumn{2}{|r|}{ Sakabu } & \multicolumn{2}{|r|}{ Kalobo } & \multicolumn{2}{|r|}{ Waijan } \\
\hline & & $\begin{array}{c}\text { Jumlah } \\
\text { sampel } \\
\text { (n) }\end{array}$ & Bobot badan & $\begin{array}{c}\text { Jumlah } \\
\text { sampel } \\
\text { (n) }\end{array}$ & Bobot badan & $\begin{array}{c}\text { Jumlah } \\
\text { sampel } \\
\text { (n) }\end{array}$ & Bobot badan \\
\hline \multirow[t]{4}{*}{1} & Jantan : & & & & & & \\
\hline & $<1$ & 0 & - & 6 & $104,50^{\mathrm{a}} \pm 54,60$ & 11 & $107,20^{\mathrm{a}} \pm 53,30$ \\
\hline & $>1 \mathrm{~s} / \mathrm{d} \leq 2$ & 4 & $144,37^{\mathrm{a}} \pm 18,73$ & 13 & $170,90^{\mathrm{b}} \pm 38.00$ & 9 & $164,30^{\mathrm{ab}} \pm 53,30$ \\
\hline & $>2$ & 4 & $291,20^{\mathrm{a}} \pm 59,40$ & 10 & $257,10^{\mathrm{a}} \pm 56,20$ & 4 & $256,90^{\mathrm{a}} \pm 52,50$ \\
\hline \multirow[t]{4}{*}{2} & Betina : & & & & & & \\
\hline & $<1$ & 12 & $103,95^{\mathrm{a}} \pm 17,86$ & 14 & $98,56^{\mathrm{a}} \pm 27,64$ & 28 & $111,07^{\mathrm{a}} \pm 37,60$ \\
\hline & $>1 \mathrm{~s} / \mathrm{d} \leq 2$ & 12 & $141,77^{\mathrm{a}} \pm 33,92$ & 46 & $130,32^{\mathrm{a}} \pm 35,11$ & 26 & $143,70^{\mathrm{a}} \pm 34,76$ \\
\hline & $>2$ & 10 & $218,30^{\mathrm{a}} \pm 33,20$ & 65 & $249,20^{\mathrm{b}} \pm 34,59$ & 40 & $224,06^{\mathrm{a}} \pm 41,08$ \\
\hline
\end{tabular}

Keterangan : Angka yang diikuti huruf yang berbeda dalam baris yang sama menunjukkan berbeda nyata $(\mathrm{p}<$ $0,05)$

Bobot badan sapi Bali jantan umur $>2$ tahun tidak berbeda karena pada umur ini ternak jantan akan dijual oleh peternak, sedangkan untuk sapi betina terdapat perbedaan dimana sapi betina di kampung Kalobo memiliki ukuran tubuh yang lebih besar. Hal ini disebabkan penggunaan ternak sebagai calon induk yang diharapkan dapat memperoleh keturunan yang besar. Bobot badan dan ukuran tubuh sapi Bali jantan maupun betina umur $<1$ tahun dan $>1$ tahun
Hal ini disebabkan penggunaan ternak jantan yang dipilih peternak untuk mengawini betina memiliki kriteria yang besar. Menurut Talib dkk.(1999), bahwa terjadi perbedaan variasi bobot badan sapi di beberapa lokasi pemeliharan sebagai akibat dari pengaruh lingkungan terutama nutrisi dan sistem pemeliharaan. 
sapi Bali Kabupaten Raja Ampat, sebagai akibat dari penjualan ternak unggul yang tidak terkontrol dalam populasi dan sistem pemeliharaan ekstensif tradisional dengan tingkat penerapan teknologi peternakan yang masih rendah oleh peternak.

\section{KESIMPULAN DAN SARAN}

Berdasarkan potensi wilayahnya, kemampuan pengembangan sapi potong di Kabupaten Raja Ampat dapat mencapai 17.792,55 ST, sehingga dari jumlah tersebut lokasi penelitian sangat potensial untuk diarahkan menjadi kawasan pengembangan sapi potong. Namum bila ditinjau dari aspek produktivitasnya sapi

\section{DAFTAR PUSTAKA}

Bamualim, AM. 2007. Produksi peternakan di Indonesia: potensi dan kendala. Di dalam: Darmono et al., penyunting. Akselerasi Agribisnis Peternakan Nasional melalui Pengembangan dan Penerapan IPTEK. Prosiding Seminar Nasional Teknologi Peternakan dan Veteriner; Bogor, 21-22 Agu 2007. hlm 13-14.

Bamualim A.M, Bess T, Chalid Talib, 2008, Arah penelitian untuk pengembangan sapi potong di Indonesia. Di dalam: Amar AL et al., editor. Pengembangan Sapi Potong untuk Mendukung Percepatan Pencapaian Swasembada Daging Sapi 2008-2010. Prosiding Seminar Nasional; Palu 24 Nov 2008. hlm 4-12.

Badan Perencanaan Pembangunan [Bappeda] Kabupaten Raja Ampat. 2008. Rencana Tata Ruang Wilayah Kabupaten Raja Ampat. Waisai: Pemerintah Daerah Kabupaten Raja Ampat.

Badan Perencanaan Pembangunan [Bappeda] Kabupaten Raja Ampat. 2009. Kabupaten Raja Ampat dalam Angka 2008. Waisai: Pemerintah Daerah Kabupaten Raja Ampat. potong yang dipelihara memiliki bobot badan yang masih rendah dibandingkan daerah lainnya, menunjukkan terjadinya penurunan performans dan mutu genetiknya. Pengurangan jumlah penjualan ternak unggul dalam populasi dan penerapan sistem integrasi tanaman ternak dapat menjadi solusinya.

Badan Pusat Statistik [BPS] Kabupaten Raja Ampat. 2014. Raja Ampat Dalam Angka 2013. Waisai: BPS Kabupaten Raja Ampat.

Dinas Pertanian Peternakan dan Perkebunan [Distannakbun] Kabupaten Raja Ampat. 2009. Laporan Tahunan Kegiatan Peternakan 2008. Waisai: Pemerintah Kabupaten Raja Ampat.

Departemen Pertanian [Deptan]. 2006. Peraturan Menteri Pertanian Nomor 54/Permentan/OT.140/10/2006 tentang Pedoman Pembibitan Sapi Potong yang Baik (Good Breeding Practice). Jakarta: Departemen Pertanian.

Handiwirawan E., Subandriyo. 2004. Potensi dan keragaman sumberdaya genetik sapi Bali . Di dalam: Setiadi et al, penyunting. Strategi Pengembangan Sapi Potong dengan Pendekatan Agribisnis dan Berkelanjutan Prosiding Lokakarya Nasional Sapi Potong. Yogyakarta, 8-9 Oktb 2004. hlm 51-56.

Hardjowigeno S., Widiatmaka, 2006. Kesesuaian Lahan dan Perencanaan Tataguna Lahan. Bogor: IPB Press.

Hidayati Nuril, C.Talib, A.Pohan. 2001. Produktivitas Padang Penggembalaan 
Rumput Alam untuk Menghasilkan Sapi Bibit di Kupang Timur, Nusa Tenggara Timur. Di dalam: Haryanto et al., penyunting. Prosiding Seminar Nasional Teknologi Peternakan dan Veteriner; Bogor, 17-18 Sept. 2007. hlm 345-352.

Musa S, dan AH Nasution. 2007. Landasan Statistika Kontemporer. Bogor: Departemen Statistika, Fakultas Matematika dan Ilmu Pengetahuan Alam, Institut Pertanian Bogor.

Rajab, 2009. Kajian pengembangan pembibitan sapi Bali di Kabupaten Raja Ampat Provinsi Papua Barat [thesis]. Bogor: Sekolah Pascasarjana, Institut Pertanian Bogor.

Rayes M.L, 2007. Metode Inventarisasi Sumber Daya lahan. Yogyakarta: Andi Publisher.

Riady M. 2004. Tantangan dan peluang peningkatan produksi sapi potong menuju 2020. Di dalam: Setiadi et al, penyunting. Strategi Pengembangan Sapi Potong dengan Pendekatan Agribisnis dan Berkelanjutan Prosiding Lokakarya Nasional Sapi Potong. Yogyakarta, 8-9 Oktb 2004. hlm 3-6.

Suratman, S., Ritung, Jaenudin. 1998. Potensi lahan untuk pengembangan ternak ruminansia besar di beberapa provinsi di Indonesia. Dalam: Karma AS. Editor, Prosiding Peternakan Pembangunan dan Komunikasi Hasil Penelitian Tanah dan Agroklimat. Bidang Pedologi. Cisarua, 4-6 Maret 1998. Bogor: Pusat Penlitian Tanah dan Agroklimat. Hlm 169-182.

Talib C., A. Bamualim dan A. Pohan. 1999. Problematika pengembangan sapi Bali dalam pemeliharaan di padang penggembalaan. Prosiding Seminar Nasional Teknologi Peternakan dan Veteriner. Puslitbangnak, Bogor. Hal 28. 
